\title{
Прикладное значение определения репродуктивного потенциала и агрессивности грибных и псевдогрибных патогенов картофеля и томата
}

\author{
А.Н. Смирнов, Е.С. Приходько, В.В. Васильченко, В.П. Хохлов, А.А. Сухоруков, \\ С.А. Кузнецов
}

Определен репродуктивный потенциал патогенов картофеля и томата грибной и псевдогрибной природы для оценки эффективности применения средств защиты растений. Выбранный подход позволяет уточнить силу и надежность фунгицидного эффекта против различных патогенов. Опыты проводили в 2013 и 2014 годах в лаборатории защиты растений РГАУ - МСХА имени К. А. Тимирязева. Для сравнения нескольких подходов, оценивающих эффективность средств защиты растений, мы провели анализ массива данных по способности азотфиксирующей ризобактерии Klebsiella planticola подавлять альтернариоз на картофеле. В последние годы это заболевание становится лидирующим на картофеле и очень существенным на томате. В полевых условиях агрессивность определяли распространенностью болезни (эквивалентна частоте инфекции), развитием болезни (степень некротизации, эквивалентна размеру некрозов) и интенсивностью спороношения, выявляемой путем микроскопического анализа полевых образцов в лабораторных условиях. Частоту инфекции, размер некрозов и интенсивность спороношения определяли по специально разработанным шкалам. Для определения интенсивности спороношения, исследуемые растительные ткани выдерживали во влажной камере и затем подвергали микроскопированию. Значения показателей развития болезни и ее возбудителя авторы ранжировали, то есть отнесли к стандартизованным диапазонам (интервалам) значений. Ранговая оценка болезней составлялась на основе закона Вебера - Фехнера. На основе данных значений для всех вариантов подсчитали биологическую, споруляционную и фитосанитарную эффективности. Далее все полученные и подсчитанные показатели перевели в ранги. Определяя наличие фунгицидного эффекта от обработок ризобактерией K. planticola, на основе подсчитанных рангов определили суммарные рейтинги всех показателей в соответствии с консервативным и интегральным подходами. Значения индексов развития, образования конидий и агрессивности позволяют рассчитывать пороги экономической вредоносности, строить краткосрочные и долгосрочные прогнозы развития фитофтороза и альтернариоза на картофеле и томате, и в результате оптимизировать системы принятия решений (СПР) и системы поддержки принятия решений (СППР) для уменьшения экологических рисков и экономических затрат на проведение защитных мероприятий. Установлено, что метод целесообразно применять при особо важных испытаниях различных химических средств защиты растений. Кроме того, определение репродуктивного потенциала патогенов картофеля грибной и псевдогрибной природы позволит оценить фитосанитарный потенциал посадок картофеля и томата, уточнить их стратегии размножения и фитосанитарные риски последующих эпифитотий на картофеле и томате.

Ключевые слова: картофель, Phytophthora infestans, Alternaria alternata, Fusarium, репродуктивный потенциал, агрессивность, фитосанитарный потенциал, фитосанитарный риск, Klebsiella planticola.

конца 1990-х годов в Московской c.- х. академии на кафедрах ботаники и фитопатологии А.Н. Смирнов и С.А. Кузнецов провели серию исследований, уточняющих жизненный и инфекционный циклы опасного патогена картофеля и томата - оомицета (псевдогриба) Phytophthora infestans [1]. В этих, по сути модельных исследованиях, авторы обосновали и дока- зали, что бесполые (зооспорангии и конидии) и половые (ооспоры) фитопатогены псевдогрибной и грибной природы в посадках картофеля - дискретные единицы учета численности фитопатогенов ( $P$. infestans, виды рода Fusarium, Alternaria alternata и A. solani) (рис.).

Научно-теоретическое значение этих результатов сводится к возможности определять потенциал размножения патогенов непосредственно в посадках картофеля, уточнять их стратегии размножения [2, 3]. Этот подход применим для решения разных вопросов в рамках общей микологии и общей фитопатологии, связанных с исследованиями анаморф и телеоморф патогенов грибной природы и грибов в целом. Также полученные результаты логично сравнивать со штатными исследованиями, проводимыми в рамках популяционной биологии фитопатогенов [4].

Обычно исследователи исходят из способности патогенов к образованию бесполых и половых структур. Сложности и коррективы вносят способность инфекционных структур патогенов (разного происхождения) к прорастанию [3-5]. Совместить исследования по образованию репродуктивных структур и их фактической способности к прорастанию сложно и удается не всегда. Возможно, это удастся сделать в будущем. К настоящему времени исходят из оценок встречаемости половых и лабораторных структур, об их способности к прорастанию судят по проводимым отдельно модельным лабораторным исследованиям.

Научно-практическое значение определения репродуктивного потенциала псевдогрибных и грибных патогенов картофеля и томата связано с возможностью уточнения их краткосрочной и долгосрочной жизнеспособности.

Цель работы: определение репродуктивного потенциала патогенов картофеля и томата грибной и псевдогрибной природы для оценки эф- 

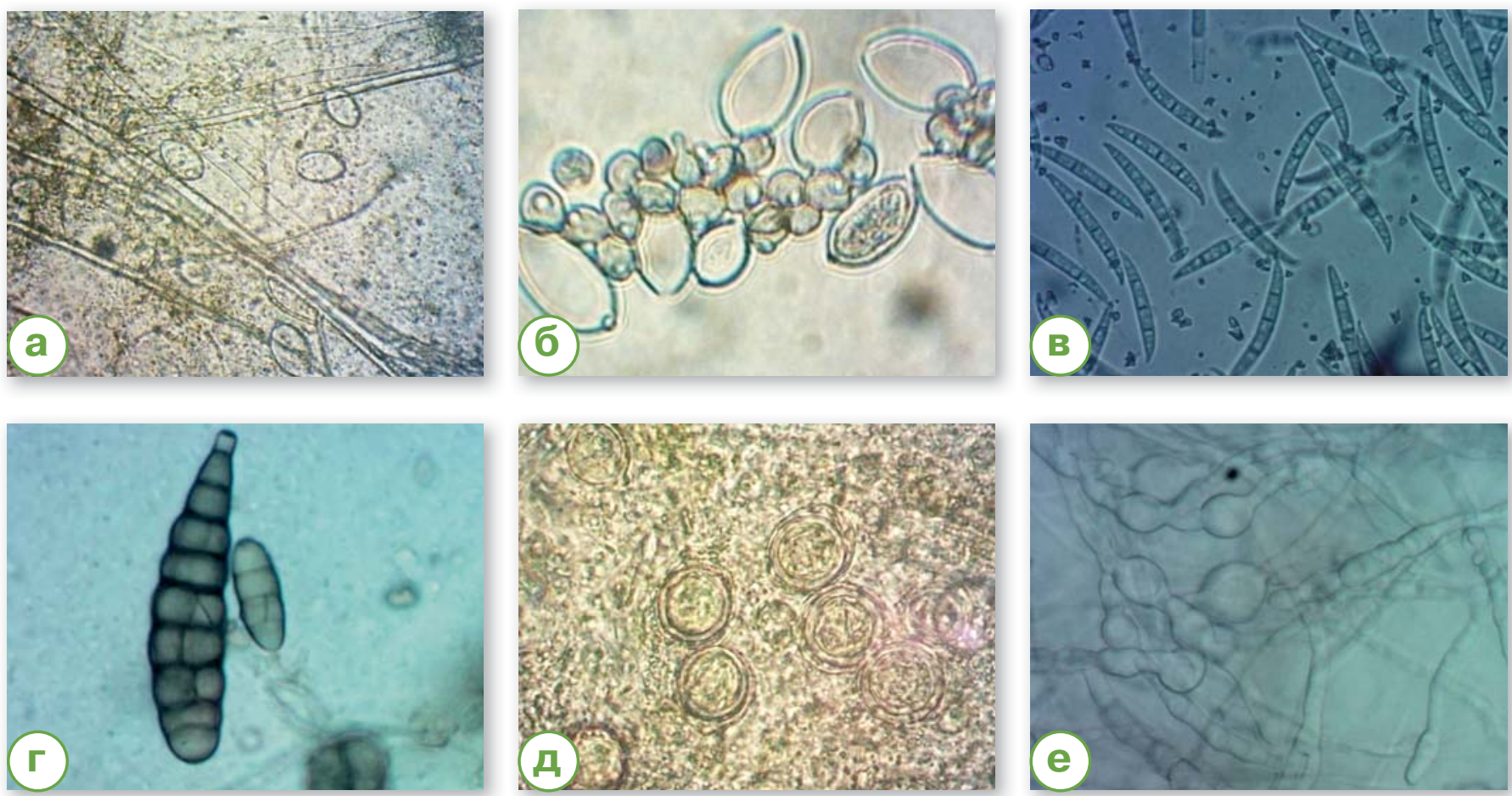

A - Зооспорангии P. infestans (20 нм). Б - Зооспорангии и инцистирующиеся прорастающие зооспоры P. infestans (5 $\mu$ м). B -

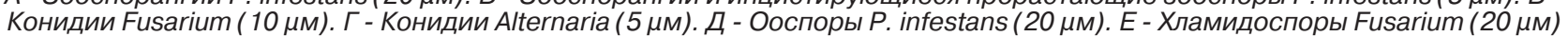

фективности применения средств защиты растений.

Условия, материалы и методы исследований. Опыты проводили в 2013 и 2014 годах на территории лаборатории защиты растений РГАУ - МСХА имени К. А. Тимирязева.

Краткосрочная жизнеспособность сводится к определению агрессивности патогенов. В лабораторных условиях этот принципиальнейший показатель определяется частотой инфекции, размером некрозов и интенсивностью спороношения [3]. В полевых условиях агрессивность определяют распространенностью болезни (эквивалентна частоте инфекции), развитием болезни (степень некротизации, эквивалентна размеру некрозов) и интенсивностью спороношения, определяемой путем микроскопического анализа полевых образцов в лабора- торных условиях. Частоту инфекции, размер некрозов и интенсивность спороношения определяли по 5- или 6-бальным шкалам [2, 3].

Частоту инфекции рассматривают как процент пораженных растений или органов растений от их общего числа. В прикладном отношении такое понимание частоты инфекции логично и понятно. Согласно альтернативному определению, частоту инфекции понимают, как эффективность клонирования - процент прорастания инфекционных структур, обычно бесполых. Этот подход отрабатывали для $P$. infestans в фитопатологических школах МГУ имени М. В. Ломоносова и ВНИИ фитопатологии под руководством Ю. Т. Дьякова, А. В. Филиппова и М. А. Кузнецовой [6]. Такое понимание частоты инфекции довольно точно с позиций микологии, но при этом уходит от практики в теорию: непонятно, сколько растений-хозяев или их органов поразилось.
Эффективность прорастания бесполых структур логично соотносится с размером некрозов: чем больше бесполых структур прорастает, тем выше степень некротизации тканей растения-хозяина. Поэтому исследования по эффективности клонирования и прорастанию бесполых структур патогена целесообразно делать в научных целях, обособленно от решения прикладных задач [5]. В связи с этим, в очень многих случаях частоту инфекции не используют в научно-прикладных исследованиях, еще это может быть связано с вероятностью ошибки опыта.

Интенсивность спороношения определяет эффективность вторичной авто- и аллоинфекции растений-хозяев, что важно для полициклических заболеваний картофеля и томата. Этот показатель будет хорошо сочетаться с данными спороловушек, проясняя общую ситуацию в посадках картофеля и томата. Определяя интенсивность спороноше-

Таблица 1. Ранги и характеристики показателей альтернариоза (распространенность и развитие), а также ранги и характеристики показателей полевых популяций A. alternata (индекс образования конидий, агрессивность) в соответствии с диапазонами значения показателей

\begin{tabular}{|c|c|c|c|c|}
\hline \multirow{2}{*}{$\begin{array}{c}\text { Диапазон значений } \\
\text { показателей }\end{array}$} & \multicolumn{2}{|c|}{ Ранги и характеристики показателей болезни } & \multicolumn{2}{|c|}{ Ранги и характеристики показателей возбудителя } \\
\hline & Распространенность (Р) & Индекс развития (ИР) & $\begin{array}{c}\text { Индекс образования } \\
\text { конидий (ИК) }\end{array}$ & $\begin{array}{c}\text { Индекс агрессивности } \\
\text { (ИА) }\end{array}$ \\
\hline $0-20,0$ & $\begin{array}{c}\text { HP1 (почти не распростра- } \\
\text { нен) }\end{array}$ & HPP1 (почти не развит) & Н1 (почти не спорулирует) & M1 (неагрессивный) \\
\hline $20,1-40,0$ & НР2 (слабо распространен & НРP2 (слабо развит) & Н2 (слабая споруляция) & M2 (мало агрессивный) \\
\hline $40,1-60,0$ & Р1 (умеренно распространен & PP1 (умеренно развит & Б1 (умеренная споруляция) & A1 (умеренно агрессивный) \\
\hline $60,1-80,0$ & Р2 (сильно распространен & РP2 (сильно развит) & Б2 (сильная споруляция) & A2 (агрессивный) \\
\hline $80,1-100$ & Р3 (очень распространен & РР3 (очень развит) & $\begin{array}{c}\text { БЗ (очень сильная споруля- } \\
\text { ция) }\end{array}$ & АЗ (очень агрессивный) \\
\hline
\end{tabular}


Таблица 2. Сравнение значений индексов развития (ИР), образования конидий (ИК) и агрессивности тернариоза на картофеле (ИА) в варианте и контроле, а также биологической (БЭ), споруляционной (СЭ) и фитосанитарной (ФЭ) и томате, и, в результаэффективности по диапазонам значений, к которым они относятся

\begin{tabular}{|c|c|c|c|c|c|}
\hline \multirow{2}{*}{ Показатели } & \multicolumn{5}{|c|}{$\begin{array}{c}\text { Ранги сравнения средних значений ИР, ИК, ИА, а также биологической, споруляционной } \\
\text { и фитосанитарной эффективности варианта и контроля }\end{array}$} \\
\hline & -3 & -1 & 0 & 1 & 3 \\
\hline \multirow{2}{*}{ ИР, ИК, ИА } & \multicolumn{5}{|c|}{$\begin{array}{c}\text { Нахождение диапазона средних значений ИР, ИК, ИА контроля относительно диапазонов } \\
\text { средних значений ИР, ИК, ИА варианта }\end{array}$} \\
\hline & $\begin{array}{l}\text { На два диапазона } \\
\text { и более влево }\end{array}$ & $\begin{array}{l}\text { На один диапазон } \\
\text { влево }\end{array}$ & $\begin{array}{l}\text { Нет, в одном диа- } \\
\text { пазоне }\end{array}$ & $\begin{array}{l}\text { На один диапазон } \\
\text { вправо }\end{array}$ & $\begin{array}{l}\text { На два диапазона } \\
\text { и более в }\end{array}$ \\
\hline \multirow{2}{*}{ БЭ, СЭ, ФЭ } & \multicolumn{5}{|c|}{ Диапазоны значений БЭ, СЭ, ФЭ } \\
\hline & 0 и менее & $0,1-10,0$ & $10,1-30,0$ & $30,1-60,0$ & $>60,0$ \\
\hline
\end{tabular}
те, оптимизировать системы принятия решений (СПР) и системы поддержки принятия решений (СППР) для уменьшения экологических рисков и экономических затрат на проведение защитных мероприятий [7].

Прикладное значение определения репродуктивного потенциала

Таблица 3. Общий эффект средств защиты на основе анализа рангов сравнения развития и биологических эффективностей схем защиты для двух обработок (первый подход: консервативный)

\begin{tabular}{|l|c|c|}
\multicolumn{2}{|c|}{ Эффект } & $\begin{array}{c}\text { Суммарный рейтинг сравнения } \\
\text { диапазонов и биологических } \\
\text { Эффективностей }\end{array}$ \\
\hline Характеристика & Ранг & $8-12$ \\
\hline Стабильный фунгицидный & ++ & $3-7$ \\
\hline Нестабильный фунгистатический & + & $-2-2$ \\
\hline Нейтральный & 0 & $-4--3$ \\
\hline Нестабильный способствующий развитию & - & $-6--5$ \\
\hline Провоцирующй & - & \\
\hline
\end{tabular}

Таблица 4. Общий потенциал, на основе рангов распространенности и индекса развития (консервативный подход), а также общий фитосанитарный потенциал, на основе рангов индексов образования конидий и агрессивности - для двух обработок

\begin{tabular}{|l|c|c|}
\multicolumn{2}{|c|}{ Общий / общий фитосанитарный потенциал } & $\begin{array}{c}\text { Суммарный рейтинг } \\
\text { диапазонов }\end{array}$ \\
\hline \multicolumn{1}{|c|}{ Характеристика } & Ранг & $17-20$ \\
\hline Максимальный & 5 & $13-16$ \\
\hline Значительный & 4 & $9-12$ \\
\hline Умеренный & 3 & $5-8$ \\
\hline Слабый & 2 & $1-4$ \\
\hline Минимальный & 1 & \\
\hline
\end{tabular}
псевдогрибных и грибных патогенов картофеля и томата сводится к оценке эффективности защитных мероприятий против них. На основе общепринятых направлений в этой области и наших исследований можно вывести два подхода.

Первый подход можно назвать консервативным. Он основан на общепринятых представлениях и связан с целесообразностью определения биологической эффективности на основе сравнения развития болезней в контрольных (без применения средства защиты) и опытных (после применения средства защиты) вариантах [8]. Некротизация тканей растений-хозяев - базовый показатель. Для непосредственного сравнения вариантов образование репродуктивных структур представляет собой вторичный показатель и не так важно. Кроме того, следует учитывать, что определение репродуктивного потенциала технически представляет собой трудоемкий процесс, требующий много времени, лабораторного персонала и применения специальных тех-

Таблица 5. Общий эффект фунгицидов, на основе анализа рангов сравнения развития, индексов образования конидий и агрессивности, а также биологических, споруляционных и фитосанитарных эффективностей схем защиты для двух обработок (второй подход: интегральный)

\begin{tabular}{l}
\multicolumn{1}{c}{ Эффект } \\
\multicolumn{1}{c}{ Характеристика } \\
\hline Стабильный фунгицидный \\
Нестабильный фунгистатический \\
Нейтральный \\
Нестабильный способствующий развитию \\
Провоцирующий
\end{tabular}

ния, можно получать текущее количество бесполых структур на и в растительныхтканях. Однакодля более емкого определения этого показателя, выявления его максимально возможных значений, исследуемые растительные ткани целесообразно выдержать во влажной камере и только после этого подвергать микроскопированию.

Долгосрочная жизнеспособность определяется наличием, способностью

Суммарный рейтинг сравнения диапазонов и биологических эффективностей

\begin{tabular}{c|c}
\hline Ранг & и биологических эффект \\
\hline++ & $23-36$ \\
\hline+ & $7-22$ \\
\hline 0 & $-6-6$ \\
\hline- & $-12--7$ \\
\hline- & $-18--13$
\end{tabular}

к консервации и способностью к прорастанию в почве стойких структур [3]. Эти данные очень важны при планировании севооборотов для минимизации развития болезней в будущем [3].

Значения индексов развития, образования конидий и агрессивности позволяют рассчитывать пороги экономической вредоносности, строить краткосрочные и долгосрочные прогнозы развития фитофтороза и аль- нологий, а также потребует много напряженных, кропотливых и узкопрофессиональных исследований [2, 3].

В данном случае образование бесполых структур и агрессивность будет определять фитосанитарный потенциал патосистемы: посадки растения-хозяина и полевую популяцию патогена. Роль фитосанитарного потенциала будет сводится к различной роли бесполых структур: их способности к инфекции растений-хозяев в настоящем (вторичная инфекция) и будущем (первичная инфекция), а также человека и теплокровных животных. К примеру, конидии Alternaria - известный аллерген, активность которого сопоставима 
Таблица 6. Распространенность и развитие альтернариоза, а также индекс образования конидий, агрессивность $A$. alternata в опытах на территории лаборатории защиты растений РГАУ - МСХА имени К. А. Тимирязева в 2013 и 2014 годы в контроле (без обработок) и в варианте с обработкой азотфиксирующей ризобактерией Klebsiella planticola

\begin{tabular}{|c|c|c|c|c|c|c|c|c|c|c|c|}
\hline \multirow{3}{*}{$\begin{array}{l}\text { Год ис- } \\
\text { следо- } \\
\text { ваний }\end{array}$} & \multirow{3}{*}{$\begin{array}{c}\text { Вариант: } \\
\text { обработка } \\
\text { клубней пе- } \\
\text { ред посадкой } \\
\text { и в течение } \\
\text { вегетацион- } \\
\text { ного сезона }\end{array}$} & \multirow{3}{*}{$\begin{array}{c}\text { Фаза } \\
\text { проведе- } \\
\text { ния учета } \\
\text { после об- } \\
\text { работки }\end{array}$} & \multicolumn{4}{|c|}{ Показатели болезни } & \multicolumn{4}{|c|}{ Показатели возбудителя } & \multirow{3}{*}{$\begin{array}{l}\text { Урожай- } \\
\text { ность, т/га }\end{array}$} \\
\hline & & & \multicolumn{2}{|c|}{$\begin{array}{l}\text { Распространение } \\
\text { (Р) }\end{array}$} & \multicolumn{2}{|c|}{$\begin{array}{c}\text { Индекс развития } \\
\text { (ИР) }\end{array}$} & \multicolumn{2}{|c|}{$\begin{array}{c}\text { Индекс образования } \\
\text { конидий (ИК) }\end{array}$} & \multicolumn{2}{|c|}{$\begin{array}{c}\text { Индекс } \\
\text { агрессивности (ИА) }\end{array}$} & \\
\hline & & & $\%$ & Ранг & $\%$ & Ранг & $\%$ & Ранг & $\%$ & Ранг & \\
\hline \multirow{2}{*}{2013} & Без обработки & \multirow{2}{*}{$\begin{array}{l}\text { Бутониза- } \\
\text { ция }\end{array}$} & 79,0 & P2 & 27,0 & HPP2 & 5,0 & $\mathrm{H} 1$ & 1,1 & M1 & \\
\hline & K. planticola & & 70,0 & P2 & 26,0 & HPP2 & 16,7 & $\mathrm{H} 1$ & 3,0 & M1 & \\
\hline \multicolumn{3}{|c|}{$\mathrm{HCP}_{05}$} & \multicolumn{2}{|c|}{$\mathrm{F} \phi<\mathrm{FT}$} & \multicolumn{2}{|c|}{$\mathrm{F} \phi<\mathrm{FT}$} & \multicolumn{2}{|c|}{$\mathrm{F} \phi<\mathrm{FT}$} & \multicolumn{2}{|c|}{$\mathrm{F} \phi<\mathrm{FT}$} & \\
\hline \multirow{2}{*}{2013} & Без обработки & \multirow{3}{*}{$\begin{array}{l}\text { После цве- } \\
\text { тения }\end{array}$} & 94,0 & P3 & 42,0 & PP1 & 3,8 & $\mathrm{H} 1$ & 1,5 & M1 & 22,8 \\
\hline & K. planticola & & 70,0 & P2 & 28,9 & HPP2 & 2,5 & $\mathrm{H} 1$ & 0,5 & M1 & 25,1 \\
\hline \multicolumn{2}{|r|}{$\mathrm{HCP}_{05}$} & & \multicolumn{2}{|c|}{19,2} & \multicolumn{2}{|c|}{$\mathrm{F} \phi<\mathrm{FT}$} & \multicolumn{2}{|c|}{$\mathrm{F} \phi<\mathrm{FT}$} & \multicolumn{2}{|c|}{$\mathrm{F} \phi<\mathrm{FT}$} & $\mathrm{F} \phi<\mathrm{FT}$ \\
\hline \multirow{2}{*}{2014} & Без обработки & \multirow{2}{*}{$\begin{array}{l}\text { Смыкание } \\
\text { рядков }\end{array}$} & 83,0 & P3 & 30,0 & HPP2 & 5,0 & $\mathrm{H} 1$ & 1,2 & M1 & \\
\hline & K. planticola & & 92,0 & P3 & 20,1 & HPP2 & 5,0 & $\mathrm{H} 1$ & 0,9 & M1 & \\
\hline \multicolumn{3}{|c|}{$\mathrm{HCP}_{05}$} & \multicolumn{2}{|c|}{$\mathrm{F} \phi<\mathrm{FT}$} & \multicolumn{2}{|c|}{8,4} & \multicolumn{2}{|c|}{-} & \multicolumn{2}{|c|}{$\mathrm{F} \phi<\mathrm{FT}$} & \\
\hline \multirow{2}{*}{2014} & \multirow[t]{2}{*}{ Без обработки } & \multirow{2}{*}{$\begin{array}{l}\text { Бутониза- } \\
\text { ция }\end{array}$} & 100 & P3 & 48,0 & PP1 & 18,8 & $\mathrm{H} 1$ & 9,0 & M1 & 11,5 \\
\hline & & & 100 & P3 & 67,0 & PP2 & 42,5 & Б2 & 28,5 & M2 & 10,8 \\
\hline \multicolumn{3}{|c|}{$\mathrm{HCP}_{05}$} & \multicolumn{2}{|c|}{$\mathrm{F} \phi<\mathrm{FT}$} & & & & & & & $\mathrm{F} \phi<\mathrm{FT}$ \\
\hline
\end{tabular}

Таблица 7. Оценка влияния обработок K. planticola на развитие альтернариоза, $A$. alternata и урожайность картофеля в опытах на территории лаборатории защиты растений РГАУ - МСХА имени К. А. Тимирязева в 2013 и 2014 годах

\begin{tabular}{|c|c|c|c|c|c|c|c|c|}
\hline \multirow{2}{*}{$\begin{array}{c}\text { Год } \\
\text { иссле- } \\
\text { дова- } \\
\text { ний }\end{array}$} & \multirow{2}{*}{$\begin{array}{c}\text { Показатель } \\
\text { болезни } \\
\text { Биологичес- } \\
\text { кая эффек- } \\
\text { тивость } \\
\text { (БЭ),\% }\end{array}$} & \multicolumn{2}{|c|}{ Показатели возбудителя } & \multirow{2}{*}{$\begin{array}{c}\text { Показатель } \\
\text { болезни } \\
\text { Биологичес- } \\
\text { кая эффек- } \\
\text { тивность } \\
\text { (БЭ),\% }\end{array}$} & \multicolumn{2}{|c|}{ Показатели возбудителя } & \multicolumn{2}{|c|}{ Показатели урожайности } \\
\hline & & $\begin{array}{c}\text { Споруляцион- } \\
\text { ная эффек- } \\
\text { тивность } \\
\text { (СЭ),\% }\end{array}$ & $\begin{array}{l}\text { Фитосанитар- } \\
\text { ная эффек- } \\
\text { тивность } \\
\text { (ФЭ),\% }\end{array}$ & & $\begin{array}{c}\text { Споруляцион- } \\
\text { ная эффек- } \\
\text { тивность } \\
\text { (СЭ),\% }\end{array}$ & $\begin{array}{l}\text { Фитосанитар- } \\
\text { ная Эффек- } \\
\text { тивность } \\
\text { (ФЭ),\% }\end{array}$ & $\begin{array}{c}\text { Прибавка } \\
\text { урожая, т/га }\end{array}$ & $\begin{array}{c}\text { Хозяйствен- } \\
\text { ная эффек- } \\
\text { тивность } \\
\text { (ХЭ),\% }\end{array}$ \\
\hline \multirow{2}{*}{2013} & \multicolumn{3}{|c|}{ Бутонизация } & \multicolumn{3}{|c|}{ После цветения } & & \\
\hline & 2,3 & - & - & 31,2 & 34,2 & 66,7 & 2,3 & 10,1 \\
\hline \multirow{2}{*}{2014} & \multicolumn{3}{|c|}{ Смыкание рядков } & \multicolumn{3}{|c|}{ Бутонизация } & & \\
\hline & 33,3 & 0 & 25,0 & - & - & - & - & - \\
\hline
\end{tabular}

Таблица 8. Ранги ИР, ИК и ИА альтернариоза и его возбудителя A. alternata, а также БЭ, СЭ и ФЭ эффективностей варианта с обработкой картофеля K. planticola

\begin{tabular}{|c|c|c|c|c|c|c|c|c|c|c|c|c|}
\hline \multirow{3}{*}{$\begin{array}{c}\text { Год } \\
\text { исследований }\end{array}$} & \multirow{2}{*}{\multicolumn{2}{|c|}{$\begin{array}{c}\text { Альтернариоз } \\
\text { Развитие }\end{array}$}} & \multicolumn{4}{|c|}{ A. alternata } & \multirow{2}{*}{\multicolumn{2}{|c|}{$\begin{array}{c}\text { Альтернариоз } \\
\text { Развитие }\end{array}$}} & \multicolumn{4}{|c|}{ A. alternata } \\
\hline & & & \multicolumn{2}{|c|}{$\begin{array}{c}\text { Образование } \\
\text { конидий }\end{array}$} & \multicolumn{2}{|c|}{ Агрессивность } & & & \multicolumn{2}{|c|}{$\begin{array}{c}\text { Образование } \\
\text { конидий }\end{array}$} & \multicolumn{2}{|c|}{ Агрессивность } \\
\hline & ИР & БЭ & ИК & $\mathrm{CЭ}$ & ИA & ФЭ & ИР & БЭ & ИК & $\mathrm{CЭ}$ & ИА & ФЭ \\
\hline \multirow{2}{*}{2013} & \multicolumn{6}{|c|}{ Бутонизация } & \multicolumn{6}{|c|}{ После цветения } \\
\hline & 0 & 1 & 0 & -3 & 0 & -3 & 1 & 1 & 0 & 1 & 0 & 3 \\
\hline \multirow{2}{*}{2014} & \multicolumn{6}{|c|}{ Смыкание рядков } & \multicolumn{6}{|c|}{ Бутонизация } \\
\hline & 0 & 1 & 0 & -1 & 0 & 0 & -1 & -3 & -3 & -3 & -1 & -3 \\
\hline
\end{tabular}

с пыльцой высших растений, конидии ния конидий и агрессивности в конFusarium участвуют в развитии мико- троле (без применения средства зов внутренних органов человека [9]. защиты) и варианте (с применениВ контексте фитосанитарии, агрес- ем средства защиты), по аналогии сивность - это принципиальнейший с биологической эффективностью, интегральный показатель краткосроч- целесообразно ввести такие поканой жизнеспособности патогенов, от- затели, как споруляционная (СЭ) ражающий способность их бесполых и фитосанитарная (ФЭ) эффективструктур к количественной реализа- ность. Их определяют по следуюции прорастания.

В этой связи, для оценки фитосанитарного потенциала после применения средства защиты растений на основе индексов образова- те соответственно, ФЭ - фитосанитарная эффективность, Ак и Ав - агрессивность в контроле и варианте соответственно. Если биологическая эффективность отражает способность средств защиты снижать степень некротизации, то споруляционная эффективность - способность снижать интенсивность образования бесполых структур (инфекционную нагрузку), фитосанитарная эффективность - способность снижать агрессивность. 
Таблица 9. Рейтинговыепоказатели и определение общего фунгицидногоэффекта согласно консервативному и интегральному подходам варианта с обработкой картофеля K. planticola в 2013 и 2014 гг.

\begin{tabular}{|c|c|c|c|}
\hline \multirow{3}{*}{$\begin{array}{c}\text { Год } \\
\text { исследований }\end{array}$} & \multicolumn{3}{|c|}{ Консервативный подход } \\
\hline & \multirow{2}{*}{$\begin{array}{l}\text { Общий } \\
\text { рейтинг }\end{array}$} & \multicolumn{2}{|r|}{ Эффект } \\
\hline & & Ранг & Характеристика \\
\hline 2013 & 3 & + & $\begin{array}{c}\text { Нестабильный фунгиста- } \\
\text { тический }\end{array}$ \\
\hline 2014 & -3 & - & $\begin{array}{l}\text { Нестабильный, способс- } \\
\text { твующий развитию }\end{array}$ \\
\hline
\end{tabular}

\begin{tabular}{c|c|c|}
\multicolumn{3}{|c|}{ Интегральный подход } \\
\hline $\begin{array}{c}\text { Общий } \\
\text { рейтинг }\end{array}$ & Ранг & \multicolumn{2}{|c|}{ Эффект } \\
\hline-2 & 0 & Нарактеристика \\
\hline-11 & - & $\begin{array}{c}\text { Нестабильльный } \\
\text { твующий развитию }\end{array}$ \\
\hline
\end{tabular}

Второй подход можно назвать интегральным. Он основан на результатах оригинальных исследований, сделанных на кафедре фитопатологии РГАУ МСХА [1-3]. Подход предназначен для определения эффективности фунгицидов на основе сравнения не только развития болезней. Сравниваются интенсивность образования бесполых структур и агрессивность возбудителей в контрольных (без применения средства защиты) и опытных (после применения средства защиты) вариантах. Образование репродуктивных структур возбудителей потребует дополнительных энергетических затрат, которые мицелий патогенов будет компенсировать за счет растения-хозяина, чем нанесет ему дополнительный ущерб. Подавление образования эффективности репродуктивных инфекционных структур - важнейший показатель эффективности фунгицидного действия. Агрессивность - интегральный показатель текущего состояния возбудителя, эффективное применение фунгицида должно снижать его.

Значения показателей развития болезни и ее возбудителя целесообразно ранжировать, то есть относить к стандартизованным диапазонам (интервалам) значений [10]. На примеpe альтернариоза и A. alternata данное ранжирование показано в табл. 1.

Известную методику AUDPC (Area Under Disease Progress Curve или площадь под кривой развития болезни) [7] не использовали из-за установленных негативных аспектов, связанных с ней: необходимость проведения очень большого количества учетов, затруднения в определении конфигурации криволинейной трапе- ции, необходимость использования чрезмерно сложных математических методов на основе интегрального исчисления. Использование рейтингов на основе суммирования полученных рангов лишено указанных методических недостатков, ранговая оценка болезней на основе закона Вебера Фехнера широко принята в фитопатологии и защите растений [10].

Соотношение значений индексов развития, образования конидий и агрессивности в варианте и контроле тому или иному диапазону также можно определенным образом проранжировать для их сравнения. Также, используя те же ранги, можно проранжировать биологическую, споруляционную и фитосанитарную эффективности варианта (табл. 2).

Суммируя ранги сравнения варианта и контроля для индекса развития (ИР) и биологической эффективности (БЭ) варианта, можно оценить эффект средства защиты в рамках первого консервативного подхода (табл. 3).

Суммируя баллы рангов диапазонов (5 баллов - наибольший диапазон, 1 балл - наименьший диапазон) распространения и индекса развития (консервативный подход) или индексов развития, образования конидий и агрессивности (интегральный подход), можно оценить общий и общий фитосанитарный потенциалы в вариантах применения средств защиты растений (табл. 4).

Суммируя ранги сравнения варианта и контроля для индексов развития (ИР), образования конидий (ИК), и агрессивности (ИА), а также биологической (БЭ), споруляционной (СЭ) и фитосанитарной (ФЭ) эффектив-

\begin{abstract}
защиты растений, мы провели
\end{abstract} лиз массива данных по способности азотфиксирующей ризобактерии Klebsiella planticola [11-13] подавлять альтернариоз на картофеле. По многим данным, в последние годы это заболевание становится лидирующим на картофеле $[14,15]$ и очень существенным на томате [16]. В варианте опыта проводили обработку ризобактерией посадочных клубней и растений в течение вегетационного периода в разные фазы, в контроле обработку ризобактерией не проводили. Вариант и контроль сравнивали по ряду показателей альтернариоза и возбудителя $A$. alternata, по ходу анализа эти значения ранжировали. Также определили урожайность сравниваемых вариантов (табл. 6).

На основе данных значений для всех вариантов подсчитали биологическую, споруляционную и фитосанитарную эффективности. Эти данные сопоставили с показателями урожайности: прибавкой в варианте и его хозяйственной эффективностью (табл. 7).

Далее все полученные и подсчитанные показатели перевели в ранги, согласно таблице 2 (табл. 8).

Выявляя наличие фунгицидного эффекта от обработок ризобактерией K. planticola, на основе подсчитанных рангов определили суммарные рейтинги всех показателей в соответствии с консервативным и интегральным подходами (табл. 9). В 2013 году между подходами было существенное различие. Интегральный подход показал отсутствие фунгицидного эффекта. Однако консервативный подход доказал наличие нестабильного фун-
Таблица 10. Рейтинговые показатели и определение общего и общего фитосанитарного потенциалов на основе определения распространенности (Р), индексов развития (ИР), образования конидий (ИК) и агрессивности (ИА) A. alternata варианта с обработкой картофеля K. planticola в 2013 и 2014 гг.

\begin{tabular}{|c|c|c|c|c|c|c|}
\hline \multirow{3}{*}{$\begin{array}{c}\text { Год исследова- } \\
\text { ний }\end{array}$} & \multicolumn{3}{|c|}{$\begin{array}{c}\text { Общий потенциал: } \\
\text { распространенность и индекс развития } \\
\text { (консервативный подход) }\end{array}$} & \multicolumn{3}{|c|}{$\begin{array}{c}\text { Фитосанитарный потенциал: } \\
\text { индексы развития, образования конидий } \\
\text { и агрессивности (интегральный подход) }\end{array}$} \\
\hline & \multirow{2}{*}{$\begin{array}{l}\text { Общий } \\
\text { рейтинг }\end{array}$} & \multicolumn{2}{|r|}{ Эффект } & \multirow{2}{*}{$\begin{array}{l}\text { Общий } \\
\text { рейтинг }\end{array}$} & \multicolumn{2}{|r|}{ Эффект } \\
\hline & & Ранг & Характеристика & & Ранг & Характеристика \\
\hline 2013 & 12 & 3 & Умеренный & 4 & 1 & Минимальный \\
\hline 2014 & 16 & 4 & Значительный & 7 & 2 & Слабый \\
\hline
\end{tabular}
гистатического эффекта. В 2014 году оба подхода показали показали отсутствие фунгицидного эффекта обработок K. planticola, некоторое провоцирование развития патогена.

Это означает, что в 2013 году K. planticola незначительно повлияла на степень некротизации, но 
не смогла уменьшить инфекционную нагрузку возбудителя альтернариоза. Фитосанитарного оздоровления посадок картофеля добиться не удалось.

В варианте с обработкой ризобактерией K. planticola ранги общего и фитосанитарного потенциалов отличались как в 2013 году, так и 2014 году (табл.10).

В 2013 году в фазу бутонизации обработка K. planticola не повлияла на развитие альтернариоза, но на фоне обработки наблюдали вспышку образования конидий и значительное повышение агрессивности A. alternata (табл. 6-8) в фазу бутонизации. Далее обработки $K$. planticola привели уже к снижению численности конидий $A$. alternata, и общий фитосанитарный потенциал по A. alternata стал в 2013 году удовлетворительным.

В параллельных исследованиях в 2013 году установили, что в листве картофеля было довольно значительное число макро- и микроконидий Fusarium, достигающее до 3 шт/ мм $^{2}$ и 12 шт/мм² соответственно.

Таким образом, в 2013 году сложился довольно неблагоприятный фитосанитарный потенциал из-за довольно значительных инфекционных нагрузок A. alternata и Fusarium. Фитосанитарный риск на следующий вегетационный сезон стал довольно высоким. При метеоусловиях 2014 года этот фитосанитарный риск воплотился в эпифитотийное развитие патокомплекса $A$. alternataFusarium на посадках картофеля, приведшего к масштабному отмиранию листьев [17].

В 2013 году применение ризобактерии K. planticola обеспечивало сдерживание альтернариоза и некоторую прибавку урожая картофеля (табл. 6, 7). В 2014 году применение ризобактерии K. planticola оптимизировали, в связи с чем ожидали дальнейшего повышения урожайности. Однако этого не произошло из-за реализации фитосанитарного риска: развития патокомплекса $A$. alternata - Fusarium [9]

Выводы. Таким образом, определение репродуктивного потенциала патогенов картофеля грибной и псевдогрибной природы для оценки эффективности применения средств защиты растений позволяет уточнить силу и надежность фунгицидного эффекта против них. Такой интегральный подход наряду с консервативным подходом целесообразно применять, например, при регистрационных испытаниях различ- ных химических средств защиты растений. Кроме того, определение репродуктивного потенциала патогенов картофеля грибной и псевдогрибной природы позволит оценить фитосанитарный потенциал посадок картофеля и томата и фитосанитарные риски последующих эпифитотий на картофеле и томате.

\section{Библиографический список}

1.Смирнов А.Н., Кузнецов С.А. Встречаемость и морфология ооспор в природных популяциях Phytophthora infestans в Московской области // Известия ТСХА. 2001. Вып. 4. С. 116-133.

2.Смирнов А.Н., Кузнецов С.А. Определение стратегий размножения и жизнеспособности полевых популяций Phytophthora infestans // Защита и карантин растений. 2006. № 3. С. 20-23.

3.Смирнов А.Н., Кузнецов С.А. Определение стратегий размножения и жизнеспособности полевых популяций Phytophthora infestans // Известия ТСХА. 2006. Вып. 4. С. 28-41.

4.Смирнов А.Н. Ооспоры Phytophthora infestans // Микология и фитопатология. 2003. Т. 37. № 1. С. 3-21.

5.Смирнов А.Н. Характеристика мексиканских штаммов Phytophthora infestans из долины Толука. II. Прорастание зооспорангиев // Микология и фитопатология. 2007. Т. 41. С. 383-391.

6.Дьяков Ю.Т., Супрун Л.М. Вероятностный метод расчета частот генов вирулентности и его применение для анализа популяций возбудителя фитофтороза картофеля Phytophthora infestans //Селскохозяйственная биология. 1984. №3. С. 111-118.

7.Анисимов Б.В. и др. Защита картофеля от болезней, вредителей и сорняков. М: Картофелевод, Издат. дом Ивана Корытова, 2009. 271 с.

8.Практикум по сельскохозяйственной фитопатологии / под ред. К.В. Попковой. М.: «Колос», 1976. 336 с.

9.Комплекс Fusarium - Alternaria как универсальный вызов / А.Н. Смирнов, Е.С. Приходько, В.П. Хохлов, Т.С. Бибик // Успехи медицинской микологии. 2018. Т. 19. С. $62-65$.

10.Смирнов А.Н. и др. Статистические подходы и методы в учете болезней растений // Реализация методологических и методических идей профессора Б. А. Доспехова в совершенствовании адаптивно-ландшафтных систем земледелия: материалы конференции. Иваново: «ПресСтоп», 2017. Т. 2. С. 57-61.

11.Селицкая О.В. и др. Особенности колонизации растений интродуцированной популяции Klebsiella planticola при воздействии стрессовых факторов // Известия ТСХА. 2013. № 1. С. 48-56.

12.Шитиква А.В. и др. Урожайность картофеля на дерновоподзолистых почвах Нечерноземья при применении регуляторов роста // Кормопроизводство. 2015. № 5. С. 22-26.

13.Приходько Е.С., Селицкая О.В., Смирнов А.Н. Влияние фунгицидов и ризобактерии Klebsiella planticola на развитие возбудителя альтернариоза картофеля // Известия ТСХА. 2016. Вып. 5. С. 68-80.

14.Козловский Б.Е., Филиппов А.В. Альтернариоз на картофеле становится более вредоносным // Защита и карантин растений. 2007. № 5. С. 12-13.

15.Золфагари А. и др. Фитофтороз и альтернариоз картофеля и томата при аномальных погодных условиях в Московской области // Защита и карантин растений. 2011. № 12. С. 40-42.

16.Смирнов А.Н., Кузнецов С.А. Фитофтороз томата // Защита и карантин растений. 2006. № 3. С. 20-23.

17.Смирнов А.Н. и др. Листостебельный комплекс фитопатогенных и сопутствующих грибов в агроценозах картофеля и томата различных регионов России // Известия ТСХА. 2015. Вып. 3. С. 36-46.

\section{Об авторах}

\section{Смирнов Алексей Николаевич,} доктор биол. наук, профессор кафедры защиты растений РГАУ - МСХА им К.А. Тимирязева, Г.н.с. отдела интен- сивного земледелия Владимирского HИИСХ. E-mail: smirnov@timacad.ru

\section{Приходько Екатерина}

Степановна, аспирант кафедры микробиологии и иммунологии РГАУ -

МСХА им. К.А. Тимирязева.

E-mail: eprihodko@rgau-msha.ru

\section{Васильченко Виктория}

Владимировна, аспирант кафедры защиты растений РГАУ - МСХА имени К.А. Тимирязева.

E-mail vasilcenkoviktoria16@gmail.com Хохлов Виктор Павлович, аспирант кафедры защиты растений РГАУ МСХА имени К.А. Тимирязева.

E-mail: spirit8930@yandex.ru

Сухоруков Александр Андреевич, магистрант кафедры защиты растений РГАУ - МСХА им. К.А. Тимирязева.

E-mail: djstalkerboy@yandex.ru

Кузнецов Сергей Александрович, с.н.с. отдела интенсивного земледелия Владимирского НИИСХ.

E-mail: infosb@mail.ru

Applied value of determination of reproductive potential and aggressiveness of fungal and pseudofungal pathogens of potato and tomato A.N. Smirnov, DSc, professor of the department of plant protection, RSAU MAA named after K.A. Timiryazev, chief research fellow of the department of intensive agriculture, Vladimir Research Institute of Agriculture (VRIA).

E-mail: smirnov@timacad.ru

E.S. Prikhodko, postgraduate student of the department of microbiology and immunology, RSAU - MAA named after K.A. Timiryazev.

E-mail: eprihodko@rgau-msha.ru

V.V. Vasilchenko, postgraduate student of the department of plant protection, RSAU MAA named after K.A. Timiryazev.

E-mail: vasilcenkoviktoria16@gmail.com V.P. Khohlov, postgraduate student of the department of plant protection, RSAU -

MAA named after K.A. Timiryazev.

E-mail: spirit8930@yandex.ru

A.A. Sukhorukov, master student of the department of plant protection, branch Phytopathology, RSAU - MAA named after K.A. Timiryazev.

E-mail: djstalkerboy@yandex.ru

S.A. Kuznetsov, senior research fellow of the department of intensive agriculture, VRIA.E-mail:infosb@mail.ru

Summary. The work purpose: determination of the reproductive potential of the pathogen of potato and tomato mushroom and pseudogenes nature to assess the effectiveness of means of protection of plants. The chosen approach allows to clarify the strength and reliability of the fungicidal effect against various pathogens. The experiments were carried out in 2013 and 2014 in the laborato- 
ry of plant protection, Russian state agrarian University - MTAA named after K. A. Timiryazev. For comparison of multiple approaches, evaluating the effectiveness of means of protection of plants, we analyzed the array data on the ability of pgpr $n$-fixing Klebsiella planticola to suppress early blight on potato. In recent years, this disease has become a leader on potatoes and very significant on tomato. In the field, their aggressiveness was determined by the prevalence of the disease (equivalent to frequency of infections), disease activity (degree of leaf tissue becoming necrotic, equivalent to necrosis) and the intensity of sporulation, detectable by microscopic analysis of field samples in the laboratory. The infection rate, necrosis size and sporulation intensity were determined by specially designed scales. To determine the intensity of sporulation, the studied plant tissues were kept in a moist chamber and then subjected to microscopy. The authors ranked the values of indicators of disease development and its causative agent, that is, referred to the standardized ranges (intervals) of values. The ranking assessment of diseases was based on the Weber - Fechner law. On the basis of these values, biological, sporulation and phytosanitary efficiency was calculated for all variants. Then all the obtained and calculated indicators were transferred to the ranks. Determining the presence of the fungicidal effect of treatments of rhizobacteria K. planticola, based on the calculated ranks determined the total ratings of all indicators in accordance with conservative and integral approaches. The values of the indices of development, conidia formation and aggressiveness allow us to calculate the thresholds of economic harmfulness, to build short-and long-term forecasts of the development of late blight and alternariosis on potatoes and tomato, and as a result to optimize decisionmaking systems (DMS) and decision support systems (DSS) to reduce environmental risks and economic costs of protective measures. It is established that the method is expedient to apply at especially important tests of various chemical means of protection of plants. In addition, the determination of the reproductive potential of potato pathogens of fungal and pseudo-fungal nature will allow to assess the phytosanitary potential of potato and tomato plantings, to clarify their breeding strategies and phytosanitary risks of subsequent epiphytoties on potatoes and tomato.

Keywords: potato, Phytophthora infestans, Alternaria alternata, Fusarium, reproductive potential, aggressiveness, phytosanitary potential, phytosanitary risk, Klebsiella planticola.

\section{Благодарная память Потомков}

В конце мая в Тимирязевской академии открылась выставка документов и книг, посвященная 130-летию со дня рождения А.Г. Лорха.

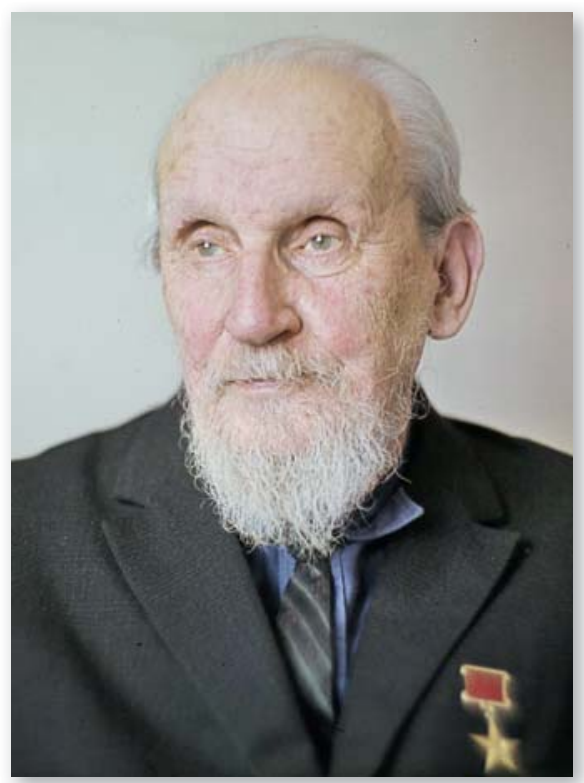

Александр Георгиевич Лорх - выдающийся советский ученый, внесший неоценимый вклад в селекцию и технологию возделывания картофеля в нашей стране. В 1920-30 годах заведующий организованной по его инициативе Кореневской картофельной станцией, которая в 1930 году была реорганизована в НИИ картофельного хозяйства. В 1931-1941 и 19481957 годах - старший научный сотрудник Института картофельного хозяйства, в 1945-1947 - доцент и профессор Московской с.- х. академии имени К. А. Тимирязева.

А.Г. Лорх вывел и способствовал внедрению в производство высокопродуктивных сортов картофеля Лорх и Кореневский, благодаря чему было обеспечено бесперебойное снабжение продовольствием фронта и тружеников тыла. За вклад в Победу в 1946 году он был награжден Сталинской премией.

В РГАУ-МСХА имени К.А. Тимирязева и ВНИИ картофельного хозяйства бережно сохраняют память об ученом и творчески развивают его наследие. В самом конце мая в Тимирязевской академии в Центральной научной библиотеке имени Н.И. Железнова открылась выставка редких документов и фотографий, посвященная 130-летию А.Г. Лорха,- «Картофель - второй хлеб». Она подготовлена усили- ями двух научных библиотек - имени Н.И. Железнова и библиотеки ВНИИ картофельного хозяйства имени А.Г. Лорха и включает в себя многочисленные, подчас уникальные материалы, которые отражают жизнь и научное наследие Александра Георгиевича научные публикации, фотографии, архивные документы, личные вещи, а также мультимедиа-презентации, доступные для посетителей.

На открытии выставки выступили представители ВНИИКХ, зам. директора, доктор техн. наук В.И. Старовойтов и доктор биол. наук В.Н. Зейрук. Виктор Иванович отметил научную интуицию А.Г. Лорха, актуальность его наследия, широту его научных интересов, идей, которые во многом опередили свое время и получают разработку сегодня.

Научный сотрудник ВНИИКХ имени А.Г. Лорха Наталия Николаевна Гордиенко рассказала собравшимся об экспонатах выставки, отражающими жизненный путь Александра Георгиевича. Серьезный этап его работы был связан с Тимирязевской c.- х. академией, где он познакомился с Н.Н. Вавиловым, В.Р. Вильямсом, С.И. Жегаловым, другими выдающимися учеными, создававшими славу отечественной аграрной науки, занимался теоретической и опытной работой.

Открытие выставки посетил и.о. декана факультета агрономии биотехнологии РГАУ-МСХА имени К.А. Тимирязева, доктор с.Х. наук, профессор В.И. Леунов. Воспоминаниями об ученом поделился и профессор кафедры генетики, биотехнологии, селекции и семеноводства этого факультета, доктор с. - х. наук А.Н. Березкин.

Гости открытия выставки получили также уникальную возможность услышать об А.Г. Лорхе от его родных - внука и правнучки ученого, Виктора Леонидовича Гайдукевича и Юлии Гайдукевич. Благодаря их рассказам, гости увидели живой образ Александра Георгиевича - блестяще образованного человека, виртуозно игравшего на фортепиано, владевшего древними и новыми языками, глубоко эрудированного специалиста, доброго, отзывчивого, скромного человека с прекрасным чувством юмора, любившего свою семью, ценившего и уважавшего коллег и сотрудников.

Выставка открыта для всех желающих на втором этаже Центральной научной библиотеки имени Н.И. Железнова до 21 июня.

P.А. Багров 